\title{
Biophysical and thermodynamic investigations on the differentiation of fluorescence response towards interaction of DNA: A pyrene based receptor versus its $\mathrm{Fe}$ (III)-complex
}

\author{
Urmila Saha $^{*}{ }^{\dagger}$, Sabyasachi Chatterjee ${ }^{\dagger}$, Malay Dolai ${ }^{*}+$, and Gopinatha Suresh Kumar ${ }^{\dagger}$ \\ † Organic and Medicinal Chemistry Division, CSIR-Indian Institute of Chemical Biology, 4, Raja S.C. Mullick \\ Road, Kolkata 700 032,W.B., India, Email: urmilasha.chem@gmail.com \\ \$Department of Chemistry, Prabhat Kumar College, Purba Medinipur 721404,W.B., India; E-mail- \\ dolaimalay@yahoo.in
}

Table S1. Crystal data and structure refinement for HL.

\begin{tabular}{|c|c|}
\hline Parameters & $\mathrm{HL}$ \\
\hline Formula & $\mathrm{C}_{27} \mathrm{H}_{17} \mathrm{~N} \mathrm{O}$ \\
\hline Formula Weight & 371.42 \\
\hline Crystal System & Monoclinic \\
\hline Space group & $\mathrm{P} 21 / \mathrm{n} \quad$ (No. 14) \\
\hline \multirow[t]{2}{*}{$a, b, c[\AA]$} & $7.717(3) \quad 7.173(3)$ \\
\hline & $31.678(12)$ \\
\hline$\alpha, \beta, \gamma\left[^{0}\right]$ & $9094.316(4)$ \\
\hline$V\left[\AA^{3}\right]$ & $1748.5(12)$ \\
\hline Z & 4 \\
\hline $\mathrm{D}$ (calc) $\left[\mathrm{g} / \mathrm{cm}^{3}\right]$ & 1.411 \\
\hline$\mu\left(\mathrm{MoK}_{\alpha}\right)[/ \mathrm{mm}]$ & 0.085 \\
\hline$F(000)$ & 776 \\
\hline Crystal Size [mm] & $0.04 \times 0.09 \times 0.12$ \\
\hline Temperature (K) & 296 \\
\hline Radiation $[\lambda, \AA]$ & 0.71073 \\
\hline Theta Min-Max [ $\left.{ }^{\circ}\right]$ & $2.7,27.3$ \\
\hline Dataset & $-9: 9 ;-9: 9 ;-40: 40$ \\
\hline Tot., Uniq.Data, R(int) & $11994,3905,0.046$ \\
\hline Observed data & 3085 \\
\hline \multicolumn{2}{|l|}{$[\mathrm{I}>2 \sigma(\mathrm{I})]$} \\
\hline $\mathrm{N}_{\text {ref }}, \mathrm{N}_{\mathrm{par}}$ & 3905,279 \\
\hline$R, \mathrm{w} R_{2}, \mathrm{~S}$ & $0.0447,0.1299,1.06$ \\
\hline
\end{tabular}




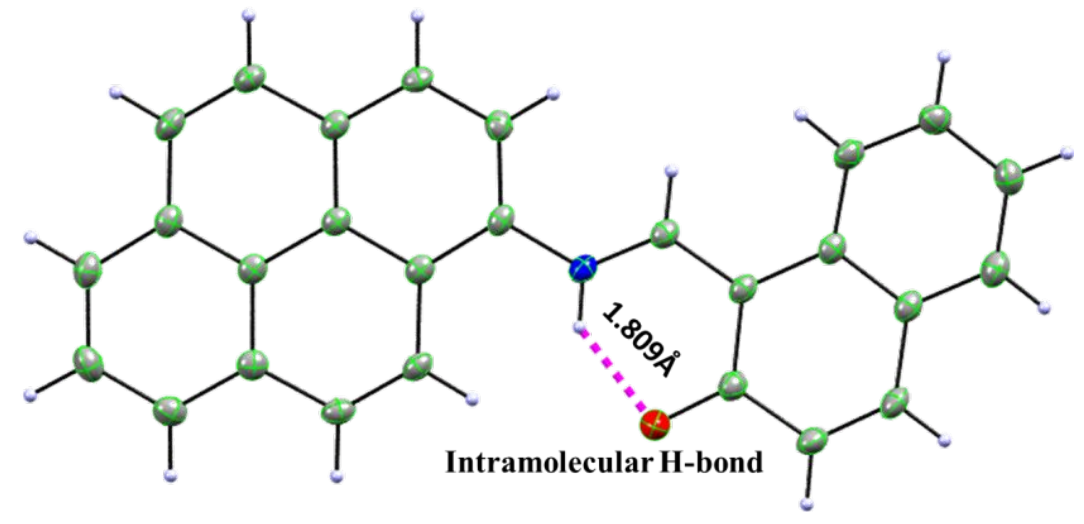

Fig.S1: The ORTEP view (50\% ellipsoid probability) of HL ligand.

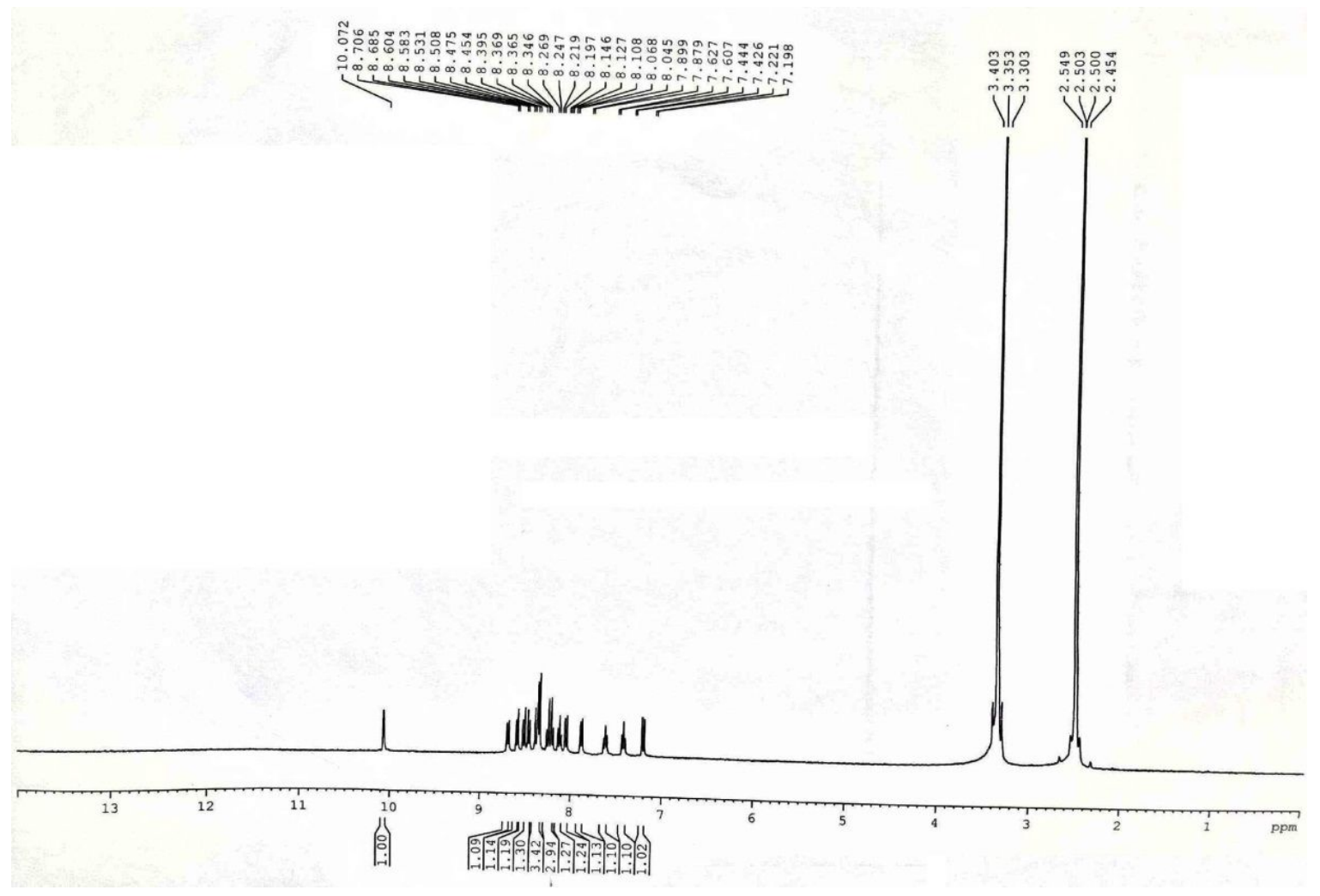

Fig.S2: ${ }^{1} \mathrm{H}-\mathrm{NMR}$ spectra of ligand $\mathbf{H L}$ 


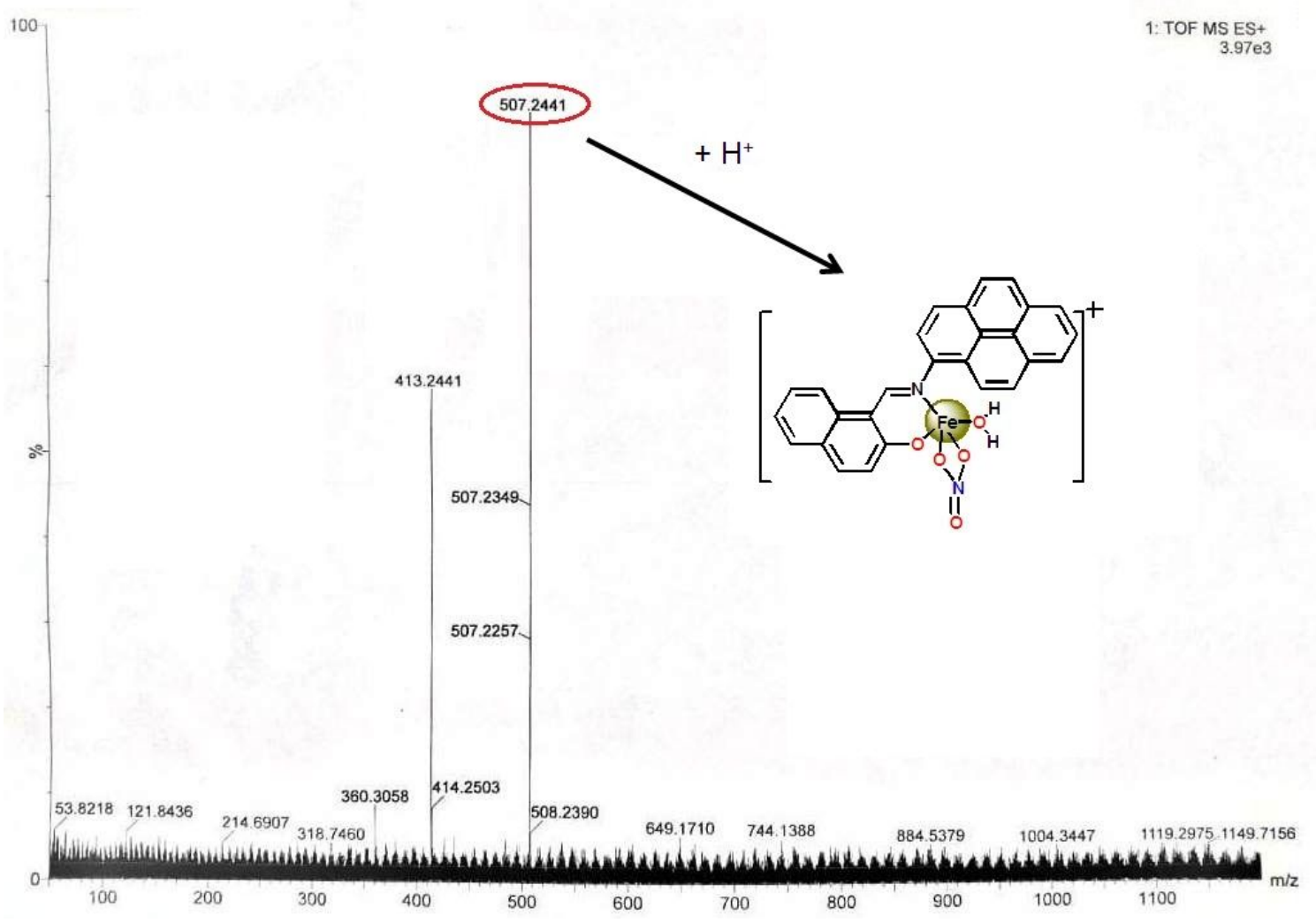

Fig.S3: ESI-MS spectra of 1.

\section{Computational details}

Ground state electronic structure calculations in gas phase of the complex $\left[\mathrm{Fe}(\mathrm{L})\left(\mathrm{NO}_{3}\right)\left(\mathrm{H}_{2} \mathbf{O}\right)\right]^{+}(\mathbf{1})$ have been carried out using $\mathrm{DFT}^{1}$ method associated with the conductor-like polarizable continuum model $(\mathrm{CPCM}){ }^{2}$ Becke's hybrid function ${ }^{3}$ with the Lee-Yang-Parr (LYP) correlation function ${ }^{4}$ was used for the study. The absorbance spectral properties in water medium for $\left[\mathrm{Fe}(\mathbf{L})\left(\mathrm{NO}_{\mathbf{3}}\right)\left(\mathrm{H}_{\mathbf{2}} \mathbf{O}\right)\right]^{+}(\mathbf{1})$, was calculated by timedependent density functional theory (TDDFT) ${ }^{\mathbf{5}}$ associated with the conductor-like polarizable continuum model and we computed the lowest 40 doublet - doublet transitions (as Fe(III) is in low-spin $\mathrm{d}^{5}$ system, so one unpaired electron with $\mathrm{s}=1 / 2$ ).

For C, N, O, H atoms we used 6-31+ G** basis set and for Fe atoms we utilized LanL2DZ as basis set for all the calculations. The calculated electron-density plots for frontier molecular orbitals were prepared by using 
Gauss View 5.1 software. All the calculations were performed with the Gaussian 09W software package. ${ }^{6}$ Gauss Sum 2.1 program ${ }^{7}$ was used to calculate the molecular orbital contributions from groups or atoms.

\section{Absorbance Studies}

The absorption spectral titrations were performed at on a Jasco V660 unit (Jasco International Co. Ltd., Hachioji, Japan) equipped with a thermoelectrically controlled cell holder and temperature controller in matched quartz cuvettes of $10 \mathrm{~mm}$ path length, following generally the methods standardized in our laboratory and reported earlier. The electronic spectra of $\mathbf{1}$ and $\mathbf{H L}$ were monitored as a function of the concentration of DNA. In each case a $20 \mu \mathrm{M}$ of $\mathbf{1}$ and $\mathbf{H L}$ (in 5\% DMSO- CP buffer (v/v), $\mathrm{pH} 7.0$ ) was titrated with increasing concentration of DNA over a range of $0-30 \mu \mathrm{M}$.

Steady-state fluorescence measurements were performed on a Shimadzu RF-5301 PC unit (Shimadzu Corporation, Kyoto, Japan) in fluorescence free quartz cuvettes of $1 \mathrm{~cm}$ path length. The excitation wavelength for both 1 and HL was $350 \mathrm{~nm}$. All measurements were performed keeping an excitation and emission band pass of $10 \mathrm{~nm}$. The sample temperature was maintained at 298.15 $\pm 1.0 \mathrm{~K}$ using an Eyela Uni Cool U55 water bath (Tokyo Rikakikai Co. Ltd., Tokyo, Japan). In each case a fixed concentration of $\mathbf{1}$ and HL [20 $\mu \mathrm{M}$ in $5 \%$ DMSO- CP buffer (v/v), pH 7.0] was titrated with increasing concentration of DNA over a range of 0-42 $\mu \mathrm{M}$.
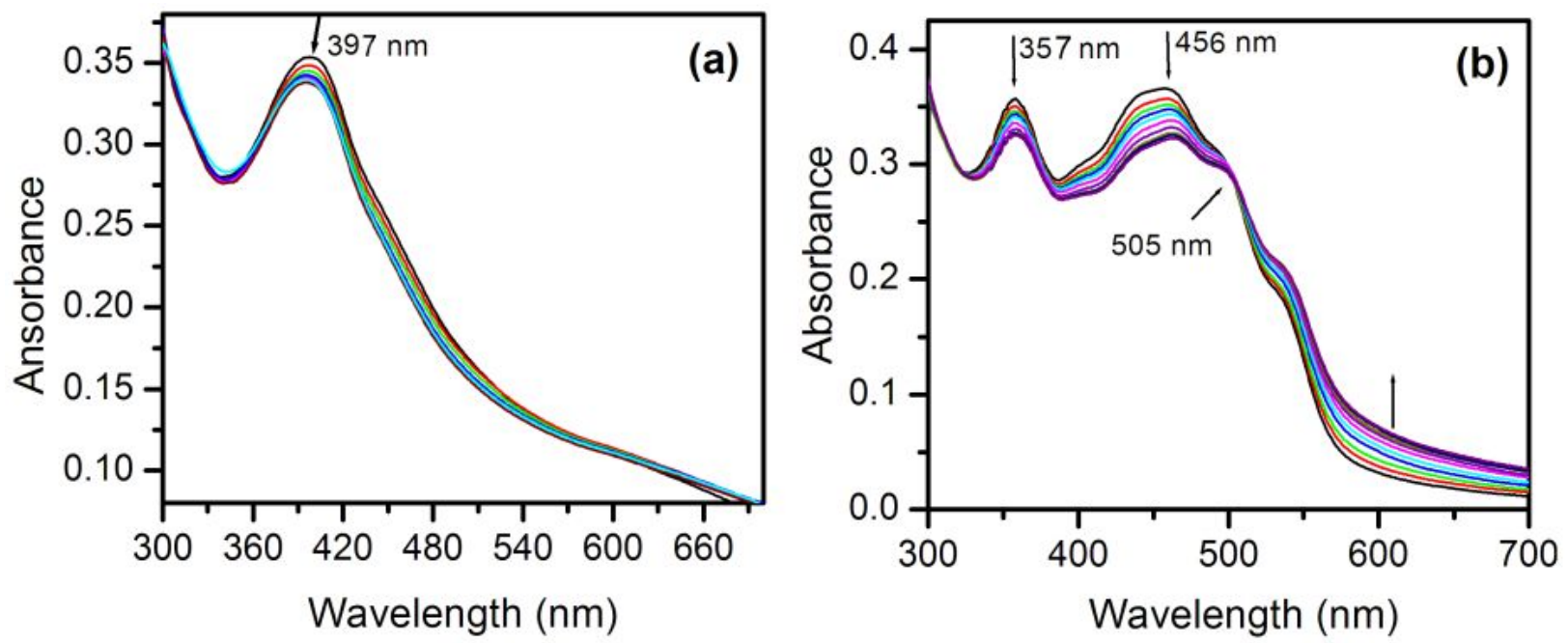

Fig. S4: Changes in absorbance for (a) 1 and (b) HL(c $=20 \mu \mathrm{M})$ with increasing concentration of [DNA] 0$30 \mu \mathrm{M}$ in $10 \mu \mathrm{M}$ citrate-phosphate (CP) buffer, $\mathrm{pH}$ 7.0. 

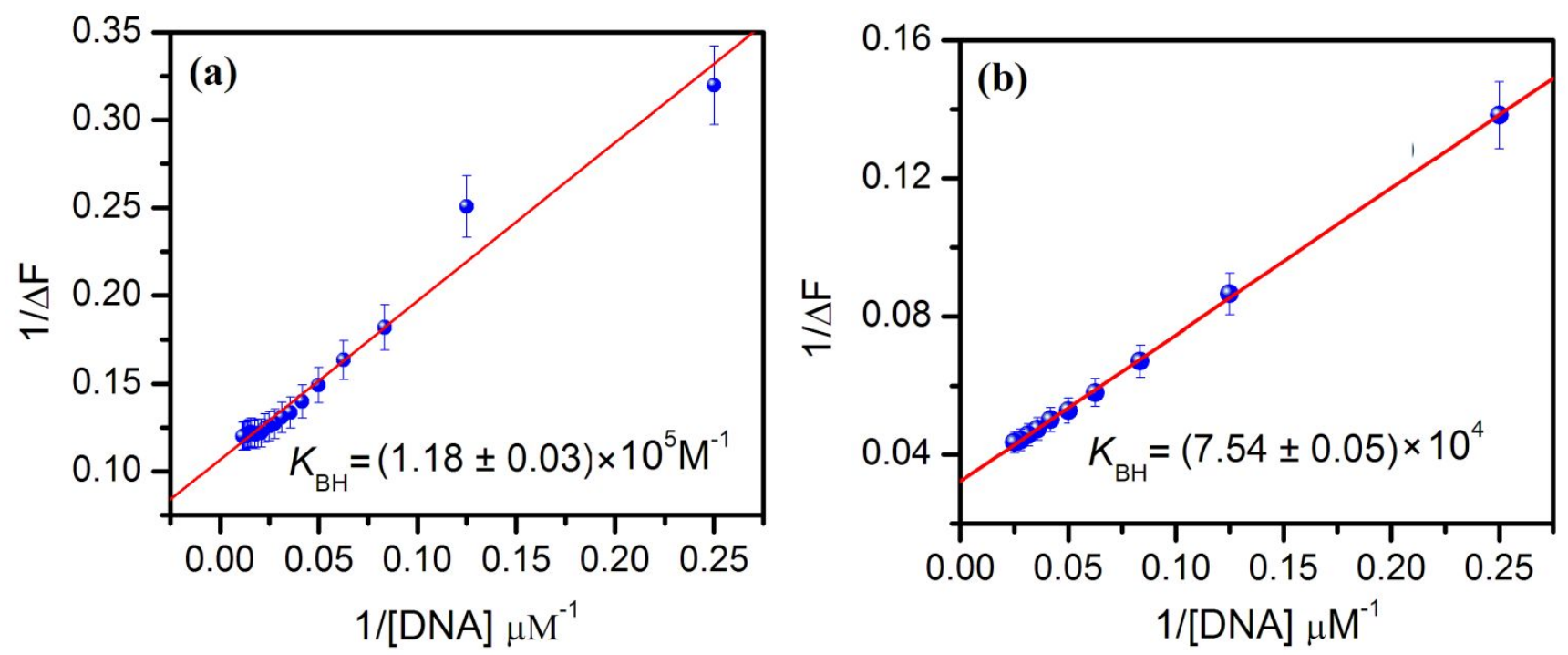

Fig. S5: Modified Benesi-Hildebrand plots for the binding of (a) 1 and (b) HL (c $=20 \mu \mathrm{M})$ to CT-DNA obtained from spectrofluorometric data.

Table S2: The comparable calculated absorbance $\lambda_{\max }$ with experimental values for $\mathbf{1}$.

\begin{tabular}{|c|c|c|l|c|c|c|c|}
\hline Complex & $\begin{array}{c}\text { Theoretical } \\
(\mathrm{nm})\end{array}$ & $\begin{array}{c}\text { Experimental } \\
(\mathrm{nm})\end{array}$ & \multicolumn{1}{|c|}{ Composition } & $\begin{array}{c}\text { Electronic } \\
\text { Transition }\end{array}$ & $\begin{array}{c}\text { Energy } \\
(\mathrm{eV})\end{array}$ & $\begin{array}{c}\text { Os } \\
\text { strength }(f)\end{array}$ \\
\hline $\mathbf{1}$ & 388 & & HOMO $\rightarrow$ LUMO+1 & $\mathrm{S}_{0} \rightarrow \mathrm{S}_{3}$ & 3.4273 & 0.0268 & 0.0163 \\
& & 397 & HOMO $\rightarrow$ LUMO+2 & & & 0.3216 & \\
& & & HOMO- $\rightarrow$ LUMO+1 & & & 0.1335 & \\
\hline
\end{tabular}




\section{Calculation of the detection limit:}

The detection limit (DL) of $\mathbf{1}$ in emission spectra for DNA was determined from the following equation1:

$\mathrm{DL}=\sigma^{*} \mathrm{Sb} 1 / \mathrm{S}$

Where $\sigma=2$ or 3 (we take 3 in this case); $\mathrm{Sb}_{1}$ is the standard deviation of the blank solution; $\mathrm{S}$ is the slope of the calibration curve.

From the graph Fig.S6, we get slope $=0.65598$, and $\mathrm{Sb}_{1}$ value is 0.69221 . Thus using the formula we get the Detection Limit for DNA $=3.16$ micromolar in emission.

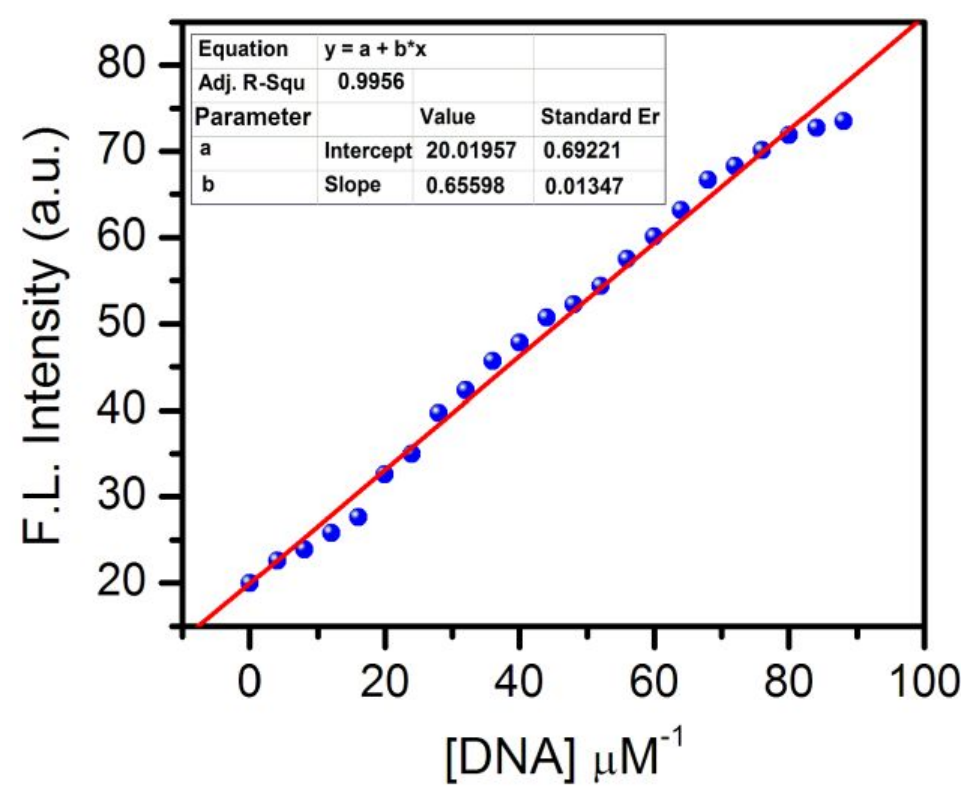

Fig. S6: (a) Changes of fluorescence of $1(c=20 \mu \mathrm{M})$ as a function of [DNA] $(0-88 \mu \mathrm{M})$ at $445 \mathrm{~nm}$.

\section{Continuous variation analysis (Job's plot)}

Job's continuous variation method ${ }^{8}$ was employed to determine the stoichiometry for the binding of HL and $\mathbf{1}$ to DNA. The fluorescence signal was recorded for solutions where the concentrations of both the DNA and compounds (HL and 1) were varied keeping the sum of their concentrations constant. The difference in fluorescence intensity $(\Delta F)$ of the compounds in the absence and presence of DNA was plotted as a function of the input mol fraction of each compounds. Break points in the the plots correspond to the mol fraction of the bound HL and /or 1 with DNA in the complex. The stoichiometry was obtained in terms of DNA- 
compounds $\left[\left(1-\chi_{\text {compounds }}\right) / \chi_{\text {compounds }}\right]$, where, $\chi_{\text {compounds }}$ denotes the mol fraction of respective compounds. The results presented are average of at least three experiments.
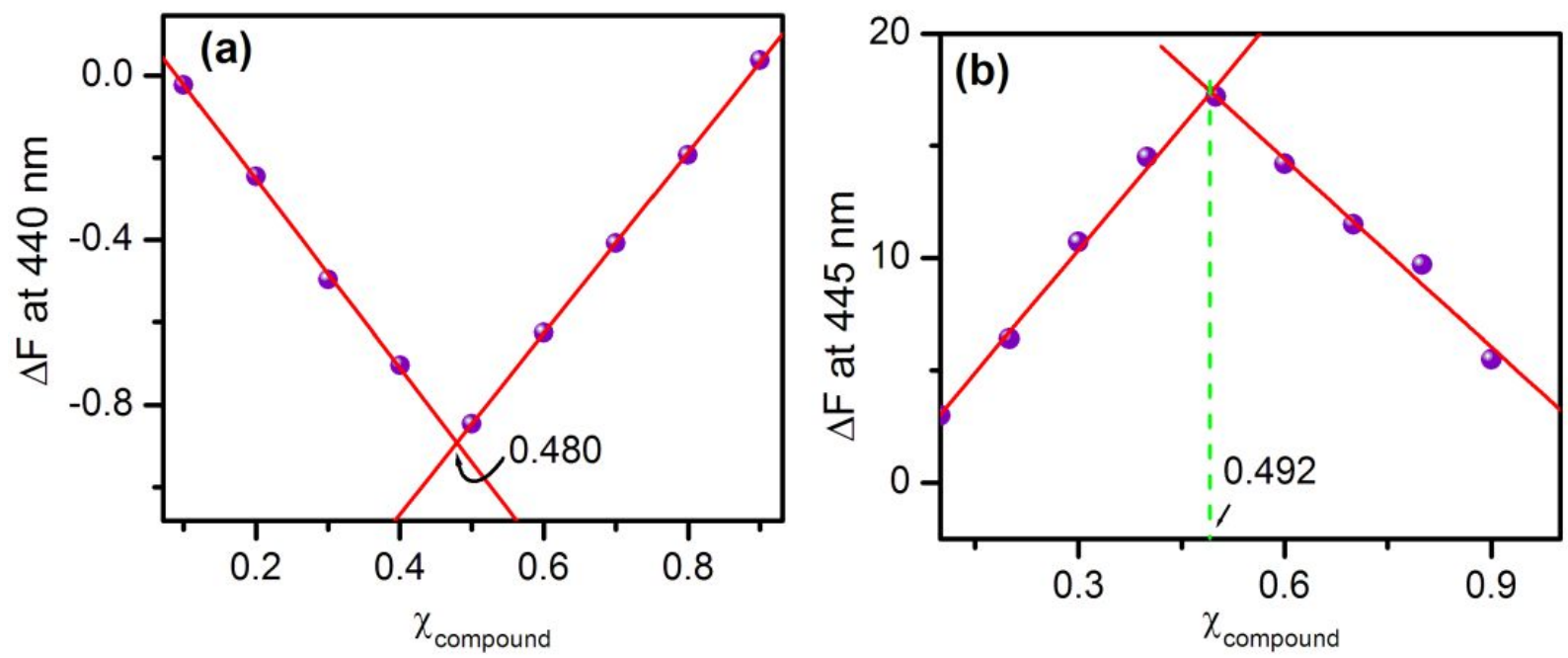

Fig. S7: Job's plot for depicting the change in fluorescence intensity versus mol fraction of (a) HL and (b) 1

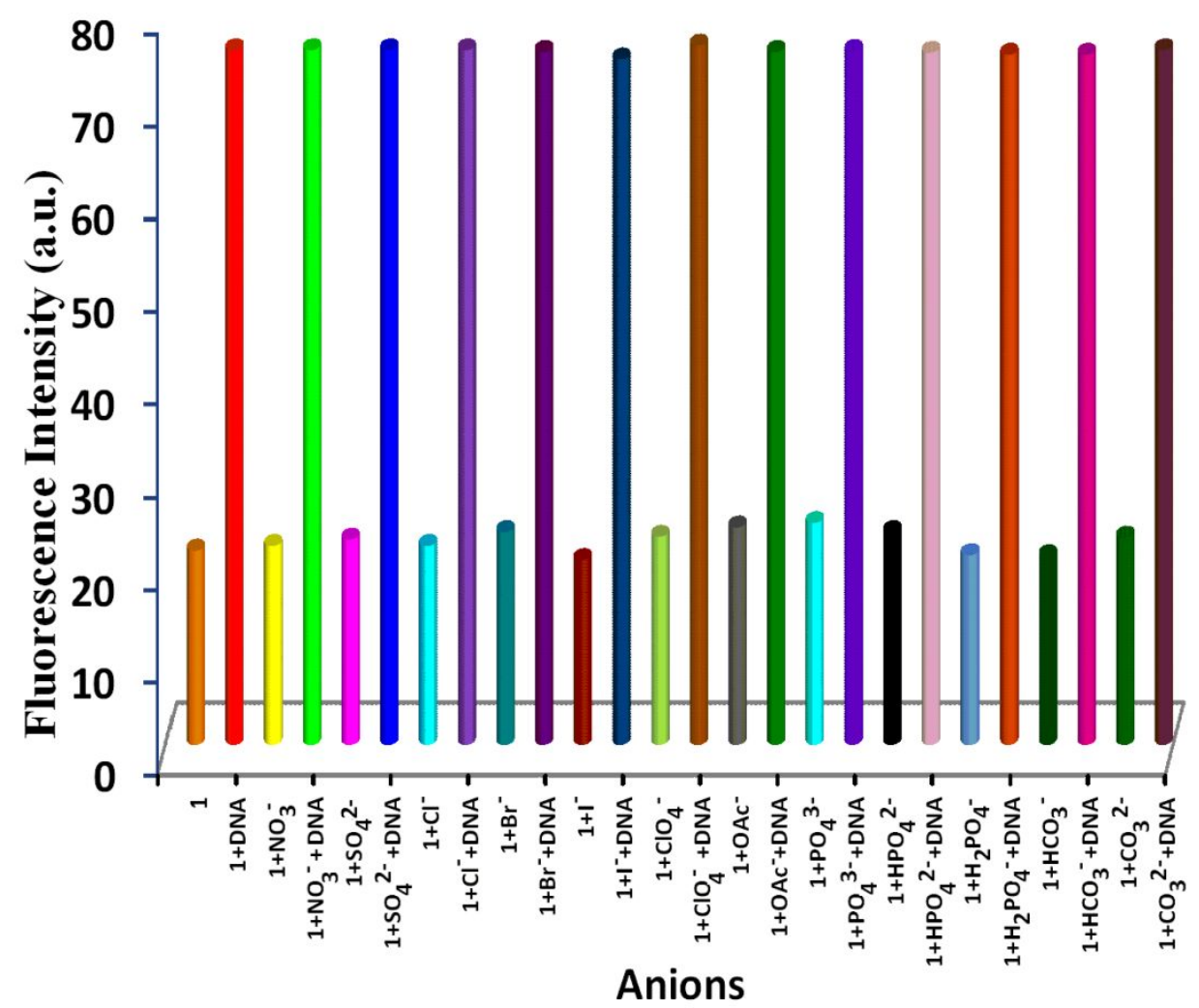

Fig. S8: Fluorescence emission of $1(20 \mu \mathrm{M})$ in presence and absence of CT-DNA ( $88 \mu \mathrm{M})$ induced by five equivalents of different anions. 


\section{Hydrodynamic studies}

Viscometric measurements were performed using a Cannon-Manning semi micro dilution viscometer immersed vertically in a thermostatic water bath at temperature 298.15 K maintained within temperature $\pm 0.5 \mathrm{~K}$. Flow times of DNA alone and DNA with different ratio of 1, HL and EB were measured in triplicate with an accuracy of \pm $0.01 \mathrm{~s}$ using a Casio electronic stop watch and the relative specific viscosity was calculated using the equation (2)

$\frac{\eta_{G P}^{I}}{\eta_{S P}}=\frac{\frac{\left(t_{\text {complex }}-t_{O D}\right)}{t_{0}}}{\frac{\left(t_{\text {control }}-t_{O P}\right)}{t_{0}}}$

where $\eta_{S D}^{s}$ and $\eta_{S D}$ are the specific viscosities of DNA in the presence and absence of the complex (HL /1) respectively, $t_{\text {complex }}$ and $t_{\text {control }}$ are the average efflux times for complex and DNA respectively and $t_{0}$ is the same for the buffer only. The relative increase in the contour length of DNA helix, $\mathrm{L} / \mathrm{L}_{\mathrm{o}}$, can be obtained from $a$ corresponding increase in the relative viscosity using the equation (3)

$$
\frac{L}{L_{0}}=\left(\frac{m_{r}}{\eta_{0}}\right)^{1 / 3}=1+\beta r
$$

where, $\mathrm{L}$ and $\mathrm{L}_{\mathrm{o}}$ are the contour lengths of DNA in the presence and absence of the complex respectively, $\eta$ and $\eta_{0}$ are the corresponding values of intrinsic viscosity (approximated by the reduced viscosity $\eta=\frac{\eta_{B p}}{c}$ ) where $\mathrm{C}$ is the DNA concentration and $\beta$ is the slope of the plot of $L / L_{o}$ versus $r$. Each experiment was repeated thrice and their average values were recorded with an accuracy of $\pm 0.01 \mathrm{~s}$.

\section{References}

(1) Parr, R. G. Density-functional theory of atoms and molecules. Horizons Quantum Chem. 1980, $5-15$.

(2) Cossi, M.; Rega, N.; Scalmani, G.; Barone, V. Energies, Structures, and electronic properties of molecules in solution with the C-PCM solvation model. J. Comput. Chem, 2003, 24, 669681.

(3) Becke, A. D. Density-functional thermochemistry. III. The role of exact exchange. J. Chem. Phys. 1993, 98, 5648-5652. 
(4) Lee, C.; Yang, W.; Parr, R. G. Development of the Colle-Salvetti correlation-energy formula into a functional of the electron density. Phys. Rev. B 1988, 37, 785-789.

(5) Bauernschmitt, R.; Ahlrichs, R. Treatment of electronic excitations within the adiabatic approximation of time dependent density functional theory. Chem. Phys. Lett. 1996, 256, 454464.

(6) Frisch, M. J.; Trucks, G. W.; Schlegel, H. B.; Scuseria, G. E.; Robb, M. A.; Cheeseman, J. R.; Scalmani, G.; Barone, V.; Mennucci, B.; Petersson, G. A.; Nakatsuji, H.; Caricato, M.; Li, X.; Hratchian, H. P.; Izmaylov, A. F.; Bloino, J.; Zheng, G.; Sonnenberg, J. L.; Hada, M.; Ehara,M.; Toyota, K.; Fukuda, R.; Hasegawa, J.; Ishida, M.; Nakajima, T.; Honda, Y.; Kitao, O.; Nakai, H.; Vreven, T.; Montgomery J. A.Jr., Peralta, J. E.; Ogliaro, F.; Bearpark, M.; Heyd, J. J.; Brothers, E.; Kudin, K. N.; Staroverov, V. N.; Kobayashi, R.; Normand, J.; Raghavachari, K.; Rendell, A.; Burant, J. C.; Iyengar, S. S.; Tomasi, J.; Cossi, M.; Rega, N.; Millam, J. M.; Klene, M.; Knox, J. E.; Cross, J. B.; Bakken, V.; Adamo, C.; Jaramillo, J.; Gomperts, R.; Stratmann, R. E.; Yazyev, O.; Austin, A. J.; Cammi, R.; Pomelli, C.; Ochterski, J. W.; Martin, R. L.; Morokuma, K.; Zakrzewski, V. G.; Voth, G. A.; Salvador, P.; Dannenberg, J. J.; Dapprich, S., Daniels, A. D.; Farkas, Ö.; Foresman, J. B.; V Ortiz, J.; Cioslowski, J.; Fox, D. J.; Gaussian Inc. 2009, Wallingford CT.

(7) O'Boyle, N. M.; Tenderholt, A. L.; Langner, K. M. CHARMM: The biomolecular simulation program B. J. Comput. Chem. 2008, 29, 839-845.

(8) Saha, U.; Khan, A. Y.; Bhuiya, S.; Das, S.; Fiorillo, G.; Lombardi, P.; Kumar, G. S. Targeting human telomeric DNA quadruplex with novel berberrubine derivatives: insights from spectroscopic and docking studies. J. Biomol. Struct. Dyn. 2019, 37, 1375-1389. 